\title{
Abdominal obesity and reduction of glomerular filtration
}

(D) Raimunda Sheyla Carneiro Dias ${ }^{1}$

Isabela Leal Calado ${ }^{2}$

Janete Daniel de Alencar ${ }^{3}$

Elane Viana Hortegal ${ }^{2}$

Elton Jonh Freitas Santos ${ }^{1}$

Dyego José de Araújo Brito ${ }^{1}$

Joyce Santos Lages ${ }^{1}$

Alcione Miranda dos Santos ${ }^{4}$

Natalino Salgado Filho ${ }^{5}$

1. Center of prevention of renal diseases of the university hospital at Brazilian university Universidade Federal do Maranhão. 2. Department of physiological sciences at Brazilian university Universidade Federal do Maranhão. 3. Postgraduation program in health sciences at Brazilian university Universidade Federal do Maranhão. 4. Public health department at Brazilian university Universidade Federal do Maranhão. 5. Department of Medicine I at Brazilian university Universidade Federal do Maranhão.

http://dx.doi.org/10.1590/1806-9282.64.04.346

\section{SUMMARY}

The objective was to evaluate the association between nutritional status and the glomerular filtration rate (GFR) in remaining quilombolas. Cross-sectional study carried out on 32 remaining quilombola communities in the municipality of Alcântara-MA. The nutritional indicators (IN) used were: body mass index (BMI); Waist circumference (WC); Waist-to-hip ratio (WHR); Waist-to-height ratio $(W H t R)$; conicity index $(C I)$ and estimated visceral adipose tissue (VAT). GFR was estimated from the CKD-EPI creatininecystatin C formula. The Shapiro Wilk test was used to evaluate the normality of the quantitative variables. In order to compare the second IN sex, the chi-square test was applied. The Anova or Kruskal-Wallis tests were used to verify the association between IN and GFR. Of the 1,526 remaining quilombolas studied, $89.5 \%$ were black or brown, $51.2 \%$ were women, $88.6 \%$ belonged to economic classes $D$ and $E$ and $61.2 \%$ were farmers or fishermen. Clinical investigation revealed $29.2 \%$ of hypertensive patients, $8.5 \%$ of diabetics and $3.1 \%$ with reduced GFR. The BMI revealed $45.6 \%$ of the remaining quilombolas with excess weight. When compared to men, women presented a higher prevalence of overweight by BMI (56.6\% vs 33.8\%, $p<0.001)$ and abdominal obesity CC (52.3\% vs $4.3 \%)$, WHR (76,5\% vs 5.8\%), WHtR (82.3\% vs 48.9\%) and VAT (27.1\% vs $14.5 \%)(p<0.001)$. Comparing the means of IN according to the GFR, it was observed that the higher the mean value of the IN lower the GFR ( $p<0.05)$. The GFR reduced with increasing mean values of nutritional indicators of abdominal obesity, regardless of sex.

KEYWORDS: Nutritional assessment. Obesity. Glomerular filtration rate. African Continental Ancestry Group.

\section{INTRODUCTION}

Obesity is a non-transmissible chronic disease, characterized by the excessive accumulation of body fat to such an extent that it causes damages to individuals' health. ${ }^{1}$

Its association with kidney disease is complex. Excess fat is a site of active production of several cytokines responsible for the higher level of inflammation and oxidative stress with deleterious renal effects. Several observational studies have demonstrated a consistent association between obesity and the risk of chronic kidney disease (CKD). However, the role of body fat in its development is still unclear. ${ }^{2}$

The pattern of body fat distribution appears to be some more important risk factor in morbid process-

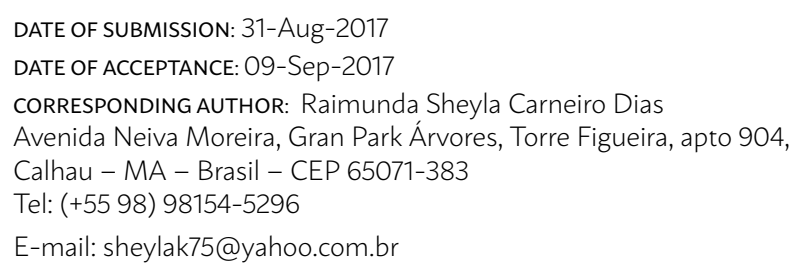

belacalado@uol.com.br, janetealencar.nutri@hotmail.com ehortegal@gmail.com, eltonfreitas86@yahoo.com.br djabrito.nefro@yahoo.com.br, joyce_lages@uol.com.br alcione.miranda@gmail.com, natalinosalgadofilho@uol.com.br 
es than total obesity. In this sense, the accumulation of adipose tissue in the abdominal region is associated with several morbidities. ${ }^{3}$ Abdominal fat, specifically visceral fat, is related to high blood pressure, insulin resistance and dyslipidemia, ${ }^{6}$ risk factors for the development of chronic kidney disease. ${ }^{4}$

For some authors, the association between obesity and CKD occurs indirectly through the influence of risk factors such as diabetes, hypertension and metabolic syndrome. ${ }^{5,6}$ Others, however, have suggested a direct link between obesity and kidney disease.,8

With regard to ethnic-racial inequalities, the situation of quilombola (descendants of Afro-Brazilian slaves and residents of quilombos) groups deserves special mention because it is a group in a situation of social vulnerability. Scholars show that blacks have a higher incidence of disease and die early, at all ages. ${ }^{9}$ In addition, the prevalence of obesity is significantly higher among blacks when compared to whites. ${ }^{10}$

The cause of the increased susceptibility of blacks to the development of CKD has not yet been well established. Some authors attribute this fact, in addition to genetic factors, to the higher rates of hypertension and type 2 diabetes mellitus found in this population, which characterize the major causes of reduction of the glomerular filtration rate in the world. ${ }^{11}$ However, in Brasil, information on renal disease in remnant quilombola populations is scarce.

In view of the complex relationship between obesity and CKD and the increased prevalence of both, especially in black individuals, the present study has aimed to evaluate the association between abdominal obesity and reduction of glomerular filtration rate in adult quilombolas in the Brazilian municipality of Alcântara, MA.

\section{METHODS}

This is a cross-sectional study carried out on 32 remaining communities of quilombos in the Brazilian municipality of Alcântara, MA. This research is linked to the project "PrevRenal - prevalence of chronic kidney disease in the Brazilian municipality of São Luís, MA, and in quilombolas communities in the Brazilian municipality of Alcântara, MA".

PrevRenal is a population-based cohort of 1,539 remaining quilombolas from the municipality of $\mathrm{Al}-$ cântara, in the north of Brazilian state of Maranhão, between August 2012 and April 2013.

Selection of participants was performed by a ran- dom probabilistic sampling process in two stages, in which the quilombos represented the first stage and the households the second stage. All adult residents of the households that were randomly selected were invited to participate in the survey.

Patients younger than 18 years of age, pregnant patients with chronic constipation disease, hematological disease, autoimmune disease, infection, chronic or acute renal disease in dialysis and those on immunosuppressive drugs or having thyroid disorders based on clinical history and physical examination of the individuals.

For constitution of the group investigated in this study, all individuals in the PrevRenal database were selected, being excluded those who presented incomplete information. The sample was finalized in 1,526 individuals.

Prior to the beginning of the survey, interviewers received training addressing the project basic procedures, as well as the need for confidentiality of the information.

The data were collected in two stages. The first stage occurred in the households through the application of an individual questionnaire for the adults present. The questionnaire consisted of the following topics: social, demographic and economic characteristics, clinical data, lifestyle, blood pressure, comorbidities and medication intake.

At the end of the interview, the participants' blood pressure (BP) was measured and they were told to fast for 12 hours for blood collection the following day, as well as to have their anthropometric measurements checked.

Blood pressure was measured using an indirect method and a digital sphygmomanometer $\left(\mathrm{Omron}^{\circledR}{ }^{\circledR}\right)$ with an appropriate cuff. Measurement was performed on the right arm with the individual sitting and at rest. Measurements were performed in triplicates, with an interval of 10 minutes, using the mean of the three measurements. Criteria proposed by the VI Brazilian Guidelines for Hypertension were adopted for BP classification.

In the second stage, on the following day, blood was collected and anthropometric measurements were checked. Such procedures were carried out by the research team in public schools or community health care clinics.

Biochemical analysis was performed by a tertiary referral laboratory with automated dosages and standardized methodology. 
Anthropometric data were measured by nutritionists and included weight, height and waist circumference (WC) and hip circumference (HC).

Weight was measured in portable electronic scales $\left(\right.$ Plena $\left.^{\circledR}\right)$ with a capacity of $150 \mathrm{~kg}$ and a variation of $50 \mathrm{~g}$. Height was measured using a portable stadiometer (Alturezata ${ }^{\circledR}$ ) with a variation of $0.1 \mathrm{~cm}$. For weight and height measurement, subjects were barefoot, wearing light clothing and in an orthostatic position.

Waist circumference (WC) was obtained at the midpoint between the last rib and the iliac crest at the time of expiration and the hip circumference (HC) in the area of greater prominence of the buttocks, using inextensible tape.

Anthropometric indicators used to assess the nutritional status were: body mass index (BMI), waisthip ratio (WHR), waist-to-height ratio (WHtR), conicity index (CI), and estimated visceral adipose tissue (eVAT).

BMI was calculated using the ratio between body weight and height squared and the cutoff used for adults was that of the World Health Organization (WHO).

WHR and WHtR were calculated for the ratios between WC and, respectively, HC and height. From the measurements of weight, height and WC, the CI was calculated. The eVAT was estimated using the predictive equation of adipose tissue $\mathrm{e}^{12}$ and WC variables for men and WC and age for women.

Cutoff points of the anthropometric indicators used for men and women were, respectively: CI $=1.25$ and $1.18^{13}$; $\mathrm{WC} \geq 88 \mathrm{~cm}$ and $\geq 102 \mathrm{~cm}$; WHR $\geq 0.85$ and $\geq 1.0$, according to criteria proposed by the World Health Organization (WHO). For WHtR = $0.50^{14}$ and eVAT $\geq 150 \mathrm{~cm}^{3,15}$ for both genders.

Blood samples obtained were used for biochemical evaluation of lipidogram, uric acid (UA), fasting glycemia (FG), creatinine (Cr) and cystatin C (CysC). In biochemical analysis, the following cutoff points were considered as normal serum levels: total cholesterol (CT) < $200 \mathrm{mg} / \mathrm{dl}$; (high-density lipoproteins) HDL-cholesterol (HDL-c) $>60 \mathrm{mg} / \mathrm{dl}$; (low-density lipoprotein) LDL-cholesterol (LDL-c) $<100 \mathrm{mg} / \mathrm{dl}$; triglycerides (TG) < $150 \mathrm{mg} / \mathrm{dl}$; GJ < $100 \mathrm{mg} / \mathrm{dl}$; UA for men $<7.2 \mathrm{mg} / \mathrm{dl}$ and women $<6.0 \mathrm{mg} / \mathrm{dl} ; \mathrm{Cr}>1.4 \mathrm{mg} /$ $\mathrm{dl}$ and $\mathrm{CysC}>1.09 \mathrm{mg} / \mathrm{dl}$.

The estimated glomerular filtration rate (eGFR) was obtained from the CKD-EPI (Chronic Kidney Disease Epidemiology Collaboration equation) formula using the creatinine and cystatin $\mathrm{C}$ values as references for the calculation. Serum creatinine was previously measured in a reference laboratory using the modified Jaffe reaction method. Serum cystatin C was measured by automated immunoturbidimetric assay using the Roche-Hitachi Cobas 6000 analysis platform. Individuals with reduced eGFR $\left(<60 \mathrm{~mL} / \mathrm{min} / 1.73 \mathrm{~m}^{2}\right)$ were referred to the Center of prevention of renal diseases of the university hospital at Brazilian university Universidade Federal do Maranhão.

The Shapiro-Wilk test was used to evaluate the quantitative variables normality.

Association of nutritional indicators and gender was tested with the chi-squared test. Analysis of variance, followed by Bonferroni correction or Kruskal-Wallis tests were used to verify the association between anthropometric indicators and GFR.

To ensure that the association between eGFR and obesity was independent of the presence of HBP (high blood pressure) and DM (diabetes mellitus), an unadjusted logistic regression with eGFR as a dependent variable and anthropometric indicators as independent variables were performed. HBP and DM were considered in an adjusted model for each anthropometric parameter investigated.

Level of significance adopted was 5\%. The data were analyzed in the general-purpose statistical software package Stata 12.0.

The present study complies with all the precepts listed in Resolution 466/12 CNS/MS (National Health Council of the Brazilian Ministry of Health), which deals with guidelines and norms regulating research involving human beings. PrevRenal was approved by the Research Ethics Committee (REC) at the university hospital at Brazilian university Universidade Federal do Maranhão (consolidated opinion 41,492/2012) and all participants in the study signed an Informed Consent Form (ICF).

\section{RESULTS}

Of the 1,526 quilombola remnants surveyed, $89.5 \%$ were black or dark-skinned, $51.2 \%$ were women, mean age was $44.4 \pm 17.3$ years. Eightynine percent belonged to the less favored economic classes D and E, 61.2\% had farming and fishing as their main occupation and $83.8 \%$ lived without a fixed income or received up to a minimum wage. As for schooling, $86.0 \%$ were illiterate or had at most elementary education. 
When it came to lifestyle, $10.8 \%$ smoked and 42.1\% drank. Clinical investigation revealed that $29.2 \%$ of the sample were hypertensive, $8.5 \%$ diabetic and 3.1\% had a reduced estimated glomerular filtration rate (eGFR).

Evaluation of nutritional status showed, through BMI, prevalence of $45.6 \%$ of overweight. Women, when compared to men, had a higher prevalence of overweight by BMI $(56.6 \%$ vs. $33.8 \%$; $p<0.001)$ and abdominal obesity evidenced by the WC $(52.3 \%$ vs. $4.3 \%$; $\mathrm{p}<0.001)$; WHR (76.5\% vs. 5.8\%; $\mathrm{p}<0.001)$; WHtR $(82.3 \%$ vs. $48.9 \%$; $<$ < 0.001$)$ and eVAT $(27.1 \%$ vs. $14.5 \%$; $<$ 0.001) (Table 1).
Regarding the biochemical evaluation, it showed elevated serum levels of total cholesterol, $38.0 \%$ of the remaining quilombolas, of triglycerides, $23.7 \%$ and LDL-c, 31.7\%. With reduced HDL-c, $42.8 \%$ of the sample were found (Table 1).

Markers of renal function revealed $4.9 \%$ of the individuals studied as presenting high values of uric acid, $1.3 \%$ of creatinine and $7.7 \%$ of cystatin $\mathrm{C}$ (Table 1).

Women, when compared to men, had a higher prevalence of high serum levels of total cholesterol $(47.8 \%$ vs. $27.6 \% ; \mathrm{p}<0.001)$ and reduced of HDL-c (53.7\% vs. 31.4\%; $\mathrm{p}<0.001)$ (Table 1).

TABLE 1. ANTHROPOMETRIC AND BIOCHEMICAL CHARACTERISTICS OF REMAINING QUILOMBOLAS, ACCORDING TO GENDER. ALCANTARA - MA, 2013.

\begin{tabular}{|c|c|c|c|c|c|c|c|}
\hline \multirow{3}{*}{ VARIABLES } & \multicolumn{6}{|c|}{ GENDER } & \multirow{3}{*}{$\begin{array}{c}\text { p. } \\
\text { value }^{\star}\end{array}$} \\
\hline & \multicolumn{2}{|c|}{ GENERAL } & \multicolumn{2}{|c|}{ Men } & \multicolumn{2}{|c|}{ Women } & \\
\hline & $\mathrm{n}$ & $\%$ & $\mathrm{n}$ & $\%$ & $\mathrm{n}$ & $\%$ & \\
\hline \multicolumn{8}{|l|}{ ANTHROPOMETRIC } \\
\hline Body Mass Index & & & & & & & $<0,001$ \\
\hline Malnutrition & 50 & 3,3 & 24 & 3,2 & 26 & 3,3 & \\
\hline Eutrophia & 783 & 51,3 & 469 & 63,0 & 314 & 40,1 & \\
\hline Overweight & 508 & 33,3 & 217 & 29,2 & 291 & 37,3 & \\
\hline Obesity & 185 & 12,1 & 34 & 4,6 & 151 & 19,3 & \\
\hline \multicolumn{8}{|l|}{ Waist Circumference } \\
\hline Altered & 441 & 28,9 & 32 & 4,3 & 409 & 52,3 & $<0,001$ \\
\hline \multicolumn{8}{|l|}{ Waist-to-Hip Ratio } \\
\hline Altered & 641 & 42,0 & 43 & 5,8 & 598 & 76,5 & $<0,001$ \\
\hline \multicolumn{8}{|l|}{ Waist-to-Height Ratio } \\
\hline Altered & 1.008 & 66,0 & 364 & 48,9 & 644 & 82,3 & $<0,001$ \\
\hline \multicolumn{8}{|l|}{ Conicity Index } \\
\hline Altered & 1.032 & 67,6 & 490 & 65,9 & 542 & 69,3 & 0,150 \\
\hline \multicolumn{8}{|l|}{ Visceral Adipose Tissue } \\
\hline Altered & 320 & 21,0 & 108 & 14,5 & 212 & 27,1 & $<0,001$ \\
\hline \multicolumn{8}{|l|}{ BIOCHEMICAL } \\
\hline \multicolumn{8}{|l|}{ Total Cholesterol } \\
\hline High & 570 & 38,0 & 201 & 27,6 & 369 & 47,8 & $<0,001$ \\
\hline \multicolumn{8}{|l|}{ Triglycerides } \\
\hline High & 362 & 23,7 & 161 & 21,6 & 201 & 25,7 & 0,062 \\
\hline \multicolumn{8}{|l|}{ HDL Cholesterol } \\
\hline Low & 652 & 42,8 & 233 & 31,4 & 419 & 53,6 & $<0,001$ \\
\hline \multicolumn{8}{|l|}{ LDL Cholesterol } \\
\hline High & 484 & 31,7 & 219 & 29,4 & 265 & 33,9 & 0,062 \\
\hline \multicolumn{8}{|l|}{ Uric Acid } \\
\hline High & 75 & 4,9 & 42 & 5,6 & 33 & 4,2 & 0,200 \\
\hline \multicolumn{8}{|l|}{ Creatinine } \\
\hline High & 20 & 1,3 & 14 & 1,9 & 6 & 0,8 & 0,056 \\
\hline \multicolumn{8}{|l|}{ Cystatin C } \\
\hline High & 118 & 7,7 & 67 & 9,0 & 51 & 6,5 & 0,069 \\
\hline
\end{tabular}


TABLE 2. ASSOCIATION BETWEEN NUTRITIONAL INDICATORS AND GLOMERULAR FILTRATION RATE OF REMAINING QUILOMBOLAS, ACCORDING TO GENDER. ALCÂNTARA MA, 2013.

\begin{tabular}{|c|c|c|c|c|}
\hline \multirow{3}{*}{ NUTRITIONAL INDICATORS } & \multicolumn{3}{|c|}{ Glomerular Filtration Rate $\left(\mathrm{mL} / \mathrm{min} / 1.73 \mathrm{~m}^{2}\right)$} & \multirow{3}{*}{$\begin{array}{c}\text { p. } \\
\text { value }^{*}\end{array}$} \\
\hline & $\geq 90$ & $60-89$ & $<60$ & \\
\hline & Average $\pm \mathrm{DP}$ & Average $\pm \mathrm{DP}$ & Average $\pm \mathrm{DP}$ & \\
\hline \multicolumn{5}{|l|}{ MEN } \\
\hline Body mass index (kg/m2) & $23,77 \pm 3,06$ & $24,20 \pm 3,56$ & $24,28 \pm 4,23$ & $0,238^{*}$ \\
\hline Waist circumference $(\mathrm{cm})$ & $82,18 \pm 9,04^{a}$ & $85,37 \pm 10,19^{A}$ & $87,69 \pm 12,58$ & $<0,001^{*}$ \\
\hline Waist-to-hip ratio & $0,88 \pm 0,06^{a}$ & $0,91 \pm 0,07^{A}$ & $0,94 \pm 0,07^{A}$ & $<0,001^{*}$ \\
\hline Waist-to-height ratio & $0,50 \pm 0,05^{a}$ & $0,53 \pm 0,06^{A}$ & $0,55 \pm 0,08^{A}$ & $<0,001^{*}$ \\
\hline Conicity index & $1,20 \pm 0,07^{a}$ & $1,25 \pm 0,08^{A}$ & $1,29 \pm 0,10^{A}$ & $<0,001^{*}$ \\
\hline Estimated visceral adipose tissue (cm3) & $69,81 \pm 57,58^{\mathrm{a}}$ & $90,12 \pm 64,91^{\mathrm{A}}$ & $104,87 \pm 80,13^{A}$ & $<0,001^{*}$ \\
\hline \multicolumn{5}{|l|}{ WOMEN } \\
\hline Body mass index (kg/m2) & $25,80 \pm 4,61$ & $26,58 \pm 5,31$ & $27,60 \pm 6,49$ & $0,028^{\#}$ \\
\hline Waist circumference $(\mathrm{cm})$ & $87,18 \pm 11,77^{\mathrm{a}, \mathrm{b}}$ & $91,06 \pm 12,18^{A, b}$ & $94,95 \pm 15,10^{B}$ & $<0,001^{*}$ \\
\hline Waist-to-hip ratio & $0,89 \pm 0,07^{a}$ & $0,92 \pm 0,07^{a}$ & $1,08 \pm 0,84^{\mathrm{A}}$ & $<0,001^{*}$ \\
\hline Waist-to-height ratio & $0,57 \pm 0,08^{a, b}$ & $0,60 \pm 0,08^{A, b}$ & $0,64 \pm 0,10^{B}$ & $<0,001^{*}$ \\
\hline Conicity index & $1,27 \pm 0,10^{a, b}$ & $1,32 \pm 0,09 \mathrm{~A}, \mathrm{~b}$ & $1,37 \pm 0,0808^{B}$ & $<0,001^{*}$ \\
\hline Estimated visceral adipose tissue (cm3) & $75,27 \pm 65,11^{a, b}$ & $143,05 \pm 58,92^{\mathrm{A}, \mathrm{b}}$ & $202,50 \pm 61,85^{B}$ & $<0,001^{*}$ \\
\hline
\end{tabular}

Anova / Bonferroni $(A>a),(B>b)$; DP-Standard Deviation; \#Kruskal Wallis

When comparing the means of nutritional indicators according to the glomerular filtration rate (GFR), it was observed that the higher the mean value of nutritional indicators, the lower the eGFR, and this difference was statistically significant in all nutritional indicators. This condition was not observed in relation to BMI in men (Table 2).

The adjusted logistic regression analysis for DM and HBP revealed that all nutritional indicators assessing abdominal obesity were associated with reduced GFR regardless of whether the subjects were hypertensive or diabetic. BMI did not demonstrate this association (Table 3).

\section{DISCUSSION}

Results of this study showed that quilombola remnants with higher mean values of nutritional indicators of obesity presented lower GFR. It was observed that women showed average values of higher nutritional indicators.

Nowadays, one aspect that has attracted attention in research on obesity is the distribution of body fat. Abdominal obesity has been considered an independent risk factor for several morbidities, representing a different risk when compared to other forms of body fat distribution. ${ }^{3}$

Some authors point out that the association between obesity and reduction of the glomerular filtration rate happens indirectly through the influence of risk factors such as diabetes, hypertension and metabolic syndrome. ${ }^{5,6}$ Others, however, have suggested a direct link between obesity and kidney disease., ${ }^{7,8}$ Obesity may lead to an increase in glomerular size and abnormalities in glomerular function. In addition, it can also lead to segmental and focal glomerulosclerosis, which worsens the scenario of proteinuria and makes even faster the loss of renal function. ${ }^{16}$

It was also observed that all nutritional indicators of abdominal obesity evaluated in this study were associated with the reduction of GFR regardless of the presence of diabetes and/or hypertension.

Research indicates that anthropometric indicators of abdominal obesity such as WC, WHR and WHtR are more sensitive predictors for GFR reduction, as well as evaluation of metabolic effects and risk factors associated with obesity. ${ }^{17,18}$ It is worth noting that BMI, although being the most frequently used anthropometric indicator in research to classify obesity, is not able to distinguish lean mass from ad- 
TABLE 3. LOGISTIC REGRESSION OF NUTRITIONAL INDICATORS AND GLOMERULAR FILTRATION RATE OF REMAINING QUILOMBOLAS ADJUSTED FOR ARTERIAL HYPERTENSION AND DIABETES. ALCÂNTARA - MA, 2013.

\begin{tabular}{|c|c|c|c|}
\hline VARIABLES & RP & Confidence Interval (95\%) & p. value ${ }^{*}$ \\
\hline \multicolumn{4}{|l|}{ Body mass index } \\
\hline Eutrophia & 1 & - & - \\
\hline Malnutrition & 1,71 & $0,38-7,75$ & 0,48 \\
\hline Overweight & 1,21 & $0,61-2,39$ & 0,59 \\
\hline Obesity & 1,52 & $0,66-3,50$ & 0,33 \\
\hline \multicolumn{4}{|l|}{ Waist circumference } \\
\hline Normal & 1 & - & - \\
\hline Altered & 1,91 & $1,04-3,51$ & 0,03 \\
\hline \multicolumn{4}{|l|}{ Waist-to-hip ratio } \\
\hline Normal & 1 & - & - \\
\hline Altered & 2,15 & $1,15-4,03$ & 0,01 \\
\hline \multicolumn{4}{|l|}{ Waist-to-height ratio } \\
\hline Normal & 1 & - & - \\
\hline Altered & 2,96 & $1,14-7,68$ & 0,02 \\
\hline \multicolumn{4}{|l|}{ Conicity index } \\
\hline Normal & 1 & - & - \\
\hline Altered & 3,34 & $1,17-9,55$ & 0,02 \\
\hline \multicolumn{4}{|c|}{ Estimated visceral adipose tissue } \\
\hline Normal & 1 & - & - \\
\hline Altered & 4,40 & $2,29-8,45$ & $<0,001$ \\
\hline
\end{tabular}

ipose mass, to differentiate the distribution of body fat or to detect the increase of fat that occurs with the advancement of age. ${ }^{19}$

Corroborating the findings of this study, researchers from a cohort of 3,107 Iranians found that abdominal obesity assessed by WC was associated with a higher risk of CKD regardless of BMI values. ${ }^{20}$ Similarly, another cohort study with elderlies in the United States has shown that increased WC was associated with faster decline in GFR. ${ }^{18}$ Dutch researchers who evaluated 7,676 subjects ${ }^{17}$ and Americans who evaluated 13,324 subjects ${ }^{8}$ have demonstrated a correlation of abdominal obesity, measured by WHR, and reduction of GFR. França et al. ${ }^{21}$, evaluating 241 hypertensive patients in the Brazilian city of São Luís, MA, showed that GFR was lower in women with higher amount of estimated visceral adipose tissue.

A multicenter cohort study by Grubbs et al. (2014) ${ }^{22}$ with 2,839 blacks and whites without renal disease at baseline has assessed the association of total obesity with GFR reduction over 10 years and found that the highest BMI was associated with a greater decline in renal function. On the other hand, Minoo et al. (2015) ${ }^{23}$, evaluating the relationship between obesity severity and the presence of renal injury in 186 individuals in Tehran (the capital of Iran and Tehran Province), have not observed a correlation between BMI and renal injury.

Thus, the association between obesity and renal disease is a complex relationship that is not yet completely understood. ${ }^{2}$ Increase in body weight may result in a greater expression of angiotensinogen in the adipocyte, with higher formation of angiotensin II in the circulation and, consequently, greater stimulus to lipogenesis. This mechanism leads to alteration of pressure homeostasis, which can also lead to changes in glomerular homeostasis. ${ }^{24}$ Obesity also affects the renal medulla structure, since adipose tissue of the renal capsule, which is more developed in individuals with excess weight, can penetrate the renal medulla. With this, there is a compression of the glomerular and tubular fil- 
tration systems, leading to an increase of arterial pressure in order to compensate the compression of nephrons, resulting in an increase of GFR, with consequent hyperfiltration and increased tubular reabsorption of sodium..$^{25,26}$

The nutritional profile of the quilombola remnants researched in this study was characterized by a high prevalence of overweight and abdominal obesity and prevalence among women was particularly alarming. These results indicate that abdominal obesity is an important health problem in quilombola communities and, more specifically, among women. ${ }^{27}$ However, despite the greater amount of abdominal fat evidenced in the remaining quilombola women, some authors have shown that black women present smaller amounts of visceral fat when compared to white women. ${ }^{28}$

The greater amount of abdominal fat in women may reflect the accumulation of fat in the abdomen area due to occurrence of pregnancy, in addition to metabolic and hormonal changes throughout life. ${ }^{29}$ Another possible explanation for this difference between genders is that the men who participated in the study worked harder in farming and fishing, developing more intense physical labor activities with little or no technological input, resulting in higher energy expenditure, while the women reported being more involved in household chores.

Corroborating the results, Soares and Barreto, ${ }^{29}$ in quilombola communities in the Brazilian state of Bahia, have concluded that overweight and abdominal obesity are important health problems, especially among women. These same authors, ${ }^{30}$ in a more recent study, have detected a high prevalence of nutritional risk for chronic noncommunicable diseases (NCDs), especially among women.

In the present study, prevalence of reduced glomerular filtration rate was considered low when compared to other studies conducted in Brasil, which found prevalence of CKD between $8.4 \%$ and 9.6\% $\%^{31,32}$ and with research involving Afro-descendant North Americans, which showed a prevalence of $19.4 \% .^{32}$ This data can be explained by the fact that it is a predominantly young population (44.4 \pm 17.3 years), in a phase in which renal changes are still in the early stages.

The study has some limitations. The first one is related to its cross-sectional design, which precludes conclusions about the impact of the variables evaluated on the reduction of glomerular filtration and the occurrence of CKD. Secondly, as a highly specific group of patients was evaluated, the results can not be automatically extrapolated to the entire remaining Brazilian quilombola population. On the other hand, the main positive aspect is the fact that it is the first study to evaluate the association between nutritional indicators of obesity in remaining quilombola communities in Brasil, filling a gap in relation to the topic.

\section{CONCLUSION}

Excess weight and abdominal obesity are an important health problem in remaining quilombola women. Glomerular filtration rate was reduced with increased abdominal obesity, regardless of gender.

\section{RESUMO}

O objetivo foi avaliar a associação entre o estado nutricional e a taxa de filtração glomerular (TFG) em remanescentes quilombolas. Estudo transversal, realizado em 32 comunidades remanescentes de quilombolas, no município de Alcântara - MA. Os indicadores nutricionais (IN) utilizados foram: índice de massa corporal (IMC); circunferência da cintura (CC); relação cintura-quadril (RCQ); relação cintura-estatura (RCEst); índice de conicidade (Índice C) e tecido adiposo visceral estimado (TAVe). A TFG foi estimada a partir da fórmula do CKD-EPI creatinina-cistatina C. O teste Shapiro Wilk foi utilizado para avaliar a normalidade das variáveis quantitativas. Para comparar os IN segundo sexo foi aplicado o teste qui-quadrado. Os testes Anova ou Kruskal-Wallis foram usados para verificar a associação entre os IN e a TFG. Dos 1.526 remanescentes quilombolas estudados, 89,5\% eram da cor preta ou parda, 51,2\% eram mulheres, $88,6 \%$ pertenciam às classes econômicas De E e 61,2\% eram lavradores ou pescadores. A investigação clínica revelou $29,2 \%$ de hipertensos, 8,5\% de diabéticos e 3,7\% com TFG reduzida. O IMC revelou 45,6\% dos remanescentes quilombolas com excesso de peso. Quando comparadas aos homens, as mulheres apresentaram maior prevalência de excesso de peso pelo IMC (56,6\% vs. 33,8\%; $p$ $<0,001)$ e obesidade abdominal CC (52,3\% vs. 4,3\%), RCQ (76,5\% vs. 5,8\%), RCEst (82,3\% vs. 48,9\%) e TAVe (27,1\% vs. 14,5\%) ( $p<0,001)$. Comparando as médias dos IN segundo a TFG observou-se que, quanto maior o valor médio dos IN, menor a TFG $(p<0,05)$. A TFG foi reduzida com o aumento dos valores médios dos indicadores nutricionais de obesidade abdominal, independentemente do sexo.

PALAVRAS-CHAVE: Avaliação nutricional. Obesidade. Taxa de filtração glomerular. Grupo com ancestrais do continente africano. 


\section{REFERENCES}

1. Fontaine KR, Redden DT, Wang C, Westfall AO, Allison DB. Years of life lost due to obesity. JAMA. 2003;289(2):187-93.

2. Ting SM, Nair H, Ching I, Taheri S, Dasgupta I. Overweight, obesity and chronic kidney disease. Nephron Clin Pract. 2009;112(3):c121-7.

3. Conde WL, Borges C. O risco de incidência e persistência da obesidade entre adultos brasileiros segundo seu estado nutricional ao final da adolescência. Rev Bras Epidemiol. 2011;14(1):71-9.

4. Sociedade Brasileira de Nefrologia (SBN). Censo brasileiro de diálise 2013. [Cited 2015 Dec 15] Available from: http://sbn.org.br/pdf/censo_2013_ publico_leigo.pdf.

5. Locatelli F, Pozzoni P, Del Vecchio L. Renal manifestations in the metabolic syndrome. J Am Soc Nephrol. 2006;17(4 Suppl. 2):S81-5.

6. Khedr A, Khedr E, House AA. Body mass index and the risk of progression of chronic kidney disease. J Ren Nutr. 2011;21(6):455-61.

7. Ejerblad E, Fored CM, Lindblad P, Fryzek J, McLaughlin JK, Nyrén O. Obesity and risk for chronic renal failure. J Am Soc Nephrol. 2006;17(6):1695702.

8. Elsayed EF, Sarnak MJ, Tighiouart H, Griffith JL, Kurth T, Salem DN, et al. Waist-to-hip ratio, body mass index, and subsequent kidney disease and death. Am J Kidney Dis. 2008;52(1):29-38.

9. Batista LE, Volochko A, Ferreira CEC, Martins V. Mortalidade da população negra adulta no Brasil. In: Fundação Nacional de Saúde, organizador Saúde da população negra no Brasil: contribuições para a promoção da equidade. Brasília: Fundação Nacional de Saúde; 2005. p.237-314.

10. Centers for Disease Control and Prevention (CDC), 2009. Behavioral Risk Factor Surveillance System (BRFSS) 2008. [Cited 2015 Dec 15] Available from: http://www.cdc.gov/brfss.

11. Matsha TE, Yako YY, Rensburg MA, Hassan MS, Kengne AP, Erasmus RT. Chronic kidney diseases in mixed ancestry South African populations: prevalence, determinants and concordance between kidney function estimators. BMC Nephrol. 2013;14:75.

12. Bonora E, Micciolo R, Ghiatas AA, Lacaster L, Alyassin A, Muggeo M, et al. Is it possible to derive a reliable estimate of human visceral and subcutaneous abdominal adipose tissue from simple anthropometric measurements? Metabolism. 1995;44(12):1617-25.

13. Pitanga F|G, Lessa I. Association of anthropometric indicators of obesity with coronary risk in adults in the city of Salvador, Bahia, Brazil. Rev Bras Epidemiol. 2007;10(2): 239-48.

14. Ashwell M, Hsieh SD. Six reasons why the waist-to-height ratio is a rapid and effective global indicator for health risks of obesity and how its use could simplify the international public health message on obesity. Int Food Sci Nutr. 2005;56(5):303-7.

15. Nagai M, Komiya H, Mori $Y$, Ohta T. Developments in estimating visceral fat area from medical examination data. I Atheroscler Thromb. 2008;15(4):193-8.

16. Bastos MG, Kirsztajn GM. Doença renal crônica: importância do diagnóstico precoce, encaminhamento imediato e abordagem interdisciplinar estruturada para melhora do desfecho em pacientes ainda não submetidos à diálise. J Bras Nefrol. 2011;33(1):93-108.

17. Pinto-Sietsma SJ, Navis G, Janssen WM, Zeeuw D, Gans RO, Jong PE; PREVEND Study Group, et al. A central body fat distribution is related to renal function impairment, even in lean subjects. Am J Kidney Dis 2003;41(4):733-41.

18. Boer IH, Katz R, Fried LF, Ix JH, Luchsinger J, Sarnak MJ, et al. Obesity and change in estimated GFR among older adults. Am J Kidney Dis. 2009;54(6):1043-51.

19. Physical status: the use and interpretation of anthropometry. Report of a WHO Expert Committee. World Health Organ Tech Rep Ser. 1995;854:1452.

20. Noori N, Hosseinpanah F, Nasiri AA, Azizi F. Comparison of overall obesity and abdominal adiposity in predicting chronic kidney disease incidence among adults. J Ren Nutr. 2009;19(3):228-37.

21. França AK, Santos AM, Salgado JV, Hortegal EV, Silva AA, Salgado Filho N Estimated visceral adipose tissue, but not body mass index, is associated with reductions in glomerular filtration rate based on cystatin $C$ in the early stages of chronic kidney disease. Int J Nephrol. 2014;2014:574267.

22. Grubbs V, Lin F, Vittinghoff E, Shlipak MG, Peralta CA, Bansal N, et al. Body mass index and early kidney function decline in young adults: a longitudinal analysis of the CARDIA (Coronary Artery Risk Development in Young Adults) study. Am J Kidney Dis. 2014;63(4):590-7.

23. Minoo F, Mahdavi-Mazdeh M, Abbasi MR, Sohrabi S. Impact of the severity of obesity on microalbuminuria in obese normotensive nondiabetic individuals. J Renal Inj Prev. 2015;4(2):34-8.

24. Kim S, Soltani-Bejnood M, Quignard-Boulange A, Massiera F, Teboul M, Ailhaud $G$, et al. The adipose renin-angiotensin system modulates systemic markers of insulin sensitivity and activates the intrarenal renin-angiotensin system. J Biomed Biotechnol. 2006;2006(5):27012.

26. Soares DA, Barreto SM. Sobrepeso e obesidade abdominal em adultos quilombolas, Bahia, Brasil. Cad Saude Publica. 2014;30(2):341-54.

25. Palatini P. Glomerular hyperfiltration: a marker of early renal damage in pre-diabetes and pre-hypertension. Nephrol Dial Transplant. 2012;27(5):1708-14.

27. Després |P, Couillard C, Gagnon |, Bergeron |, Leon AS, Rao DC, et al. Race, visceral adipose tissue, plasma lipids, and lipoprotein lipase activity in men and women: the Health, Risk Factors, Exercise Training, and Genetics (HERITAGE) family study. Arterioscler Thromb Vasc Biol. 2000;20(8):1932-8

28. Gomes F, Telo DF, Souza HP, Nicolau JC, Halpern A, Serrano Júnior CV. Obesidade e doença arterial coronariana: papel da inflamação vascular. Arq Bras Cardiol. 2010;94(2):273-9.

29. Soares DA, Barreto SM. Indicadores nutricionais combinados e fatores associados em população quilombola no Sudoeste da Bahia, Brasil. Cien Saúde Colet. 2015;20(3):821-32.

30. Lima AO, Kesrouani S, Gomes RA, Cruz J, Mastroianni-Kirstajn G. Population screening for chronic kidney disease: a survey involving 38,721 Brazilians. Nephrol Dial Transplant. 2012;27(Suppl 3):iii135-8.

31. Bastos RMR, Bastos MG, Ribeiro LC, Bastos RV, Teixeira MTB. Prevalência da doença renal crônica nos estágios 3, 4 e 5 em adultos. Rev Assoc Med Bras. 2009;55(1):40-44

32. Mendy VL, Azevedo MJ, Sarpong DF, Rosas SE, Ekundayo OT, Sung JH, et al. The association between individual and combined components of metabolic syndrome and chronic kidney disease among African Americans: the Jackson Heart Study. PLoS ONE. 2014;9(7):e101610. 